\title{
Use of Somatostatin Analog in Management of Carcinoid Syndrome
}

\author{
AARON VINIK and ALI REZA MOATTARI
}

\begin{abstract}
Carcinoid tumors are the most frequent gut neuroendocrine tumors accounting for more than $50 \%$ of all tumors of the gastroenteropancreatic (GEP) axis. These tumors appear to derive from a stem cell line capable of differentiating into a variety of malignant cells that secrete many different peptides and amines. The symptoms of carcinoid tumors are often non-specific, vague abdominal pain that may precede the diagnosis by a median of 9 years. Carcinoid syndrome occurs in $<10 \%$ of patients. We evaluated the effects of SMS 201-995 in 14 such patients, 12 with diarrhea, 8 with flushing, 3 with wheezing, one with tricuspid valve incompetence, 6 with facial teleangiectasia, 3 with a pellagra type dermatosis and one with myopathy. Diarrhea was abolished or significantly reduced in $83 \%$, flushing in 100\%, wheezing in 100\%, and myopathy improved in the one patient. Blood serotonin was resistant to change, urine 5 HIAA fell in $75 \%$, and most gut neuropeptide hormones apart from somatostatin were suppressed. Tumor growth appeared to be slowed in 2/3 of cases treated for up to 4 years. The analog of somatostatin appears to be a useful addition to the therapeutic armamentarium for carcinoid tumors and the symptom complex.
\end{abstract}

KEY WORDS: somatostatin; carcinoid tumors; carcinoid syndrome; diarrhea; flushing..

Carcinoids are the most common gut endocrine tumors. They derive from a primitive stem cell and are generally found in the gut wall. They frequently metastasize to the regional lymph nodes and the liver. The likelihood of metastases is related to tumor size. If less than $1 \mathrm{~cm}$, the incidence of metastases is less than $2 \%$ but rises to $100 \%$ with tumors greater than $2 \mathrm{~cm}$ in diameter. The carcinoid syndrome occurs in less than $10 \%$ of patients with tumors, and is especially common in tumors of the ileum and jejunum, but also occurs with bronchial, ovarian, and other carcinoids (1).

Of all gastroenteropancreatic (GEP) tumors, carcinoids account for $55 \%$, insulinomas $17 \%$, tumors

\footnotetext{
Manuscript received March 8, 1988; accepted November 14, 1988.

From the Departments of Internal Medicine and Surgery, University of Michigan, Ann Arbor, Michigan 48109.

Address for reprint requests: Aaron Vinik, Department of Internal Medicine, University of Michigan, Ann Arbor, Michigan 48109 .
}

of unknown types $15 \%$, gastrinomas $9 \%$, vipomas $2 \%$ and the remainder $2 \%$. The incidence of these tumors is around 1.5 cases per 100,000 of the general population, accounting for $13-34 \%$ of all tumors of the small bowel and $17-46 \%$ of all malignant tumors of the small bowel (2).

Although carcinoids are classically tumors of enterochromaffin and argentaffin cells of the digestive tract, the term "carcinoid tumor" can be expanded to cover "gut" tumors of paracrine and endocrine-like cells of unknown function $(3,4)$. It is now established that these tumors are of neuroendocrine origin and derive from a primitive stem cell that may differentiate into any one of a variety of adult endocrine secreting cells: B cell and insulinoma; A cell and glucagonoma; D cell and somatostatinoma; and the PP cell and PPoma, or cells capable of producing ACTH, GHRH, VIP, substance P, GRF, calcitonin, and the EC cell with its ability to cosecrete amines such as serotonin and 
Cell Differentiation:

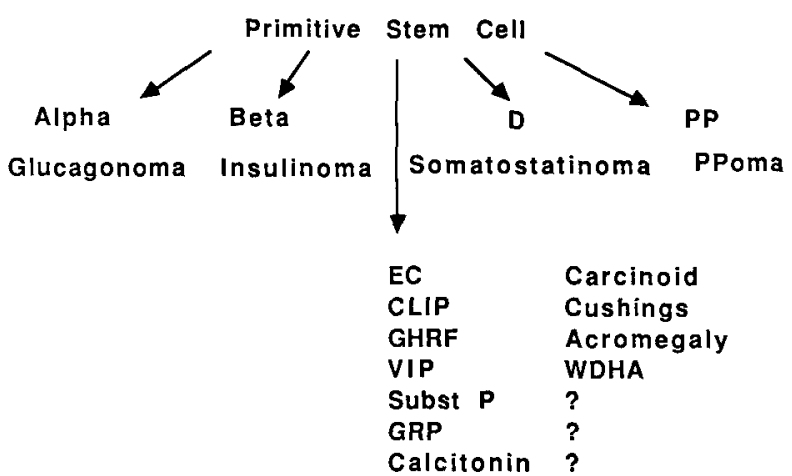

Fig 1. The differentiation of gastroenteropancreatic tumors from a primitive stem cell.

the peptide motilin. This proposed evolutionary development is outlined in Figure 1. At any one point in time these cells may secrete one humor, whereas at other times the peptide or amine secreted may differ and yield an entirely different clinical syndrome. Indeed, metastases are known to secrete hormones that differ from the parent tumor and different metastases may secrete different hormones.

The natural history of carcinoid tumor growth and the resultant symptom complex is illustrated in Figure 2. The tumors are slow growing and may be present for years without overt symptoms, and thus escape attention. In the early stages, vague abdominal pain goes undiagnosed and is invariably ascribed to "irritable bowel or spastic colon." With metastases to the liver, the correct diagnosis is generally arrived at with a latency, however, of many years. Even then, mistaken identity is not uncommon and unless biopsy material is examined for the neuronal glycolytic enzyme, neuron-specific enolase or, the secretory peptide, chromogranin (5),

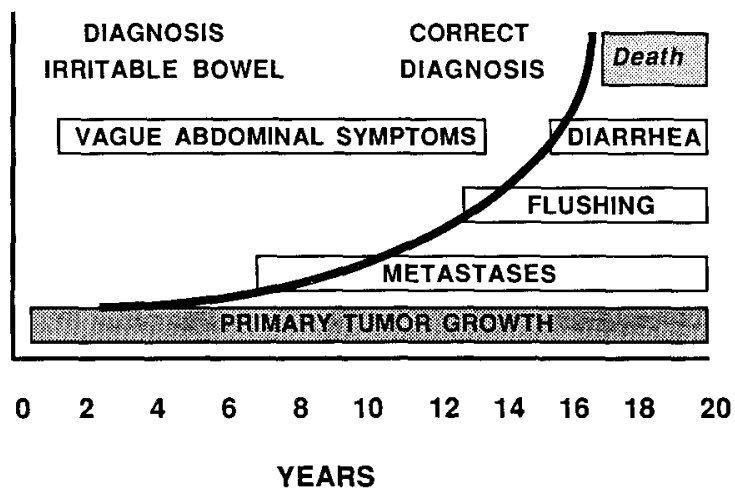

Fig 2. Natural history of carcinoid. tumors may be erroneously labeled as adenocarcinomas with a negative impact upon survival and attitudes to management.

The general prognosis in carcinoid is excellent. Based upon a world literature of some 2837 cases the median survival for all cases is $82 \%$ (6). If, however, the tumor is localized, then the five-year survival is $94 \%$, decreasing to $64 \%$ with regional lymph node involvement, and $18 \%$ with distant metastases. Davis et. al (1) reported a mean survival of 38 months from the first episode of flushing with $25 \%$ living for more than six years. With regional lymph node involvement, the figure falls to about 14 months (7), and with urinary 5HIAA in excess of $150 \mathrm{mg} / 24 \mathrm{hr}$ or inoperable tumors the median survival is only 11 months (6).

Carcinoid syndrome occurs in less than $10 \%$ of patients with carcinoid tumors. The principle features of carcinoid syndrome include flushing, sweating, wheezing, diarrhea, abdominal pain, cardiac fibrosis, and pellagra dermatosis. Diarrhea is found in $83 \%$ of cases, flushing in $49 \%$, dyspnea in $20 \%$, and bronchospasm in $6 \%$ (8). The relationship between diarrhea and flushing is variable. One can occur without the other, and there may be no temporal relationship between the two. The specific etiologic agent(s) for each of the protean manifestations of the carcinoid tumors is not known. Serotonin $(9,10)$, prostaglandins $(11), 5$-hydroxytryptophan (12-14), substance P $(15,16)$, kallikrein (17), histamine (18), dopamine (19) and neuropeptide $\mathrm{K}$ (20) are thought to be involved in the clinical manifestations of carcinoid tumors. In addition, symptoms may be related to overproduction of peptides of the proopiomelanocortin family, betaendorphin and enkephalin. Pancreatic polypeptide and motilin levels are often raised (21), which may be an important marker of tumor activity and provide a means of monitoring tumor growth and response to therapy rather than contributing to specific symptomatology.

Feldman and O'Dorisio (22) examined the proportion of 43 patients with carcinoid with increased levels of serotonin and various other vasoactive peptides. Serotonin, measured either as its urinary excretion, urinary 5HIAA, or whole blood serotonin, was raised in $84 \%$ of patients with carcinoid tumors and was within normal limits in patients with other tumors and miscellaneous illnesses. Urinary 5 HIAA alone had a $73 \%$ sensitivity and $100 \%$ specificity. Seven of their patients had normal urinary 5HIAA levels, but other indices of serotonin 

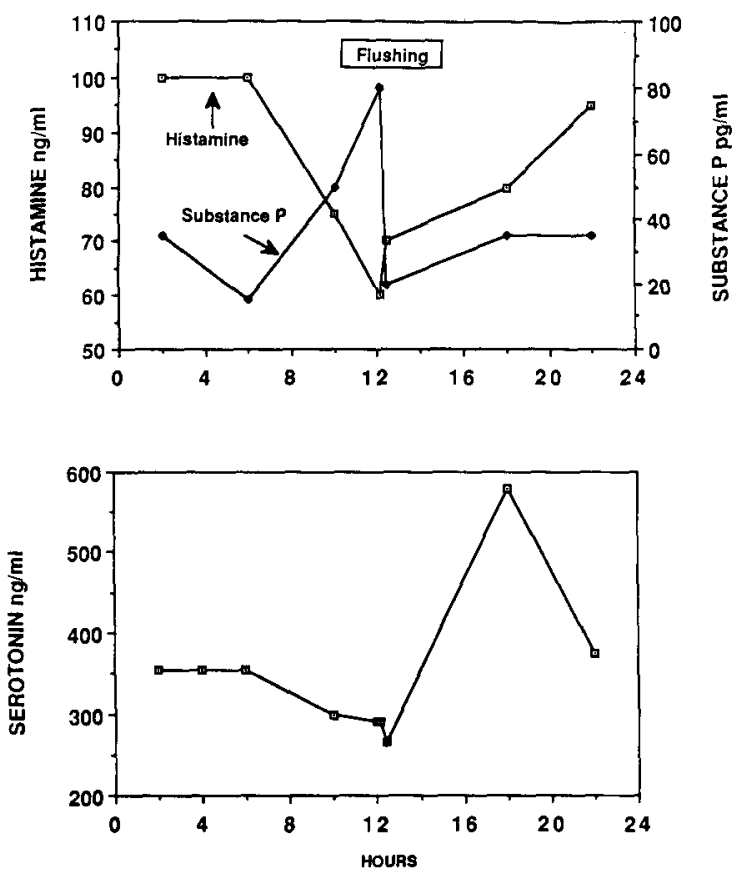

Fig 3. Blood levels of histamine, substance $\mathbf{P}$, and serotonin in relation to an episode of flushing. Note the rise in substance $P$ precedes the flush.

production were elevated. Neurotensin and substance $\mathrm{P}$ were raised in 43 and $32 \%$ of patients and had specificity values of 60 and $85 \%$, respectively. False positives occurred in 23 and $26 \%$ of patients with conditions other than carcinoid. Motilin and somatostatin were raised in 14 and $50 \%$, respectively. These humors may, however, have a better relationship etiologically with the flushing than serotonin. Figure 3 illustrates a patient who experienced a flushing episode while being monitored continuously. The flushing episode was preceded by a rise in substance $\mathrm{P}$ and followed by a rise in serotonin and a fall in histamine levels in blood. Whether this proves to be universal remains to be seen.

Even though these humors may not prove to be involved in the flushing or diarrhea, they may prove useful as an aid in the localization of ostensibly occult carcinoid tumors. We have previously reported on a patient with a 10-year history of flushing initially precipitated by alcohol ingestion and four years of watery diarrhea (16). Whole-body venous sampling with measurements of plasma serotonin erroneously localized the tumor to the neck, for which a negative exploration was carried out. However, substance $\mathrm{P}$ levels correctly localized the tumor to the ovary and excision was followed by cure. The false localization was presumably due to serotonin binding to platelets, rendering it difficult to identify gradients in plasma in relation to tumor overproduction.

Patients with carcinoid may suffer as a result of the endocrine syndrome and/or tumor growth. Surgical removal of the primary tumor is the treatment of choice for small and localized tumors or alleviation of any obstructive symptoms, but surgical cure of carcinoid is almost impossible in the presence of intraabdominal and hepatic metastases. Different chemotherapeutic agents (23) and surgery or arterial embolization (24) have been used with variable success, but eventual relapse with increasing resistance to the drugs is encountered (6). Since carcinoid is a slow-growing tumor, even patients with extensive metastatic disease can enjoy a normal quality of life so long as the endocrine syndrome is quiescent. Different chemical agents such as methysergide, cyproheptadine, heparin, phenothiazines, alpha-adrenergic antagonists, corticosteroids, $\mathrm{H}_{1}$ and $\mathrm{H}_{2}$ antihistamine blockers, and symptomatic treatment of diarrhea with opioids, and codeine have been tried with variable results (6). Since somatostatin has very broad inhibitory effects, somatostatin-14 has been used successfully to suppress diarrhea and flushing in patients with carcinoid tumors (25), but its clinical use is limited by its short half-life (26), with the resulting need for continuous intravenous infusion. With the advent of the long-acting somatostatin analog (SMS 201-995) (27), it has been used in the treatment of different neuroendocrine tumors including carcinoid. We have evaluated the effects of SMS 201-995 on clinical, biochemical, and tumor growth in 14 patients with carcinoid tumors.

\section{PATIENT SELECTION}

Patients with histologically proven carcinoid tumors were enrolled in the study. The clinical features of 14 patients with carcinoid tumors are shown in Table 1. There were eight males and six females with a mean age of 60 (range 46-80 years). The time interval from diagnosis to initiation of SMS therapy ranged from 2 to 96 months when some patients underwent surgery and/or chemotherapy. Of 14 patients, 12 had diarrhea, 8 had flushing, 3 wheezing, 1 had tricuspid thickening and insufficiency, 6 had teliangiectasia, and 3 had a dermatosis. 
Table 1. Clinical features of Patients with Carcinoid Tumors

\begin{tabular}{|c|c|c|c|c|c|c|c|c|c|c|c|c|c|}
\hline \multirow{2}{*}{$\begin{array}{l}\text { Patients } \\
\text { No. and } \\
\text { initials }\end{array}$} & \multirow{2}{*}{$\begin{array}{l}\text { Age } \\
(y r)\end{array}$} & \multirow{2}{*}{ Sex } & \multirow{2}{*}{$\begin{array}{l}\text { Months } \\
\text { since } \\
\text { diagnosis }\end{array}$} & \multicolumn{5}{|c|}{$\begin{array}{l}\text { Carcinoid } \\
\text { symptoms and } \\
\text { signs* }\end{array}$} & \multirow{2}{*}{$\begin{array}{c}\text { Other } \\
\text { symptoms }\end{array}$} & \multirow[b]{2}{*}{ Other signs } & \multirow{2}{*}{$\begin{array}{l}\text { Primary } \\
\text { site }\end{array}$} & \multirow{2}{*}{$\begin{array}{l}\text { Distant } \\
\text { metastases }\end{array}$} & \multirow[b]{2}{*}{ Prior treatments } \\
\hline & & & & $D$ & $F V$ & $W V L$ & $L T$ & $D$ & & & & & \\
\hline 1. J.B. & 55 & $\mathbf{M}$ & 4 & + & +- & - & - & - & & Hepatomegaly & Ileum & Liver & $\begin{array}{l}\text { Resection of primary } \\
\text { and debulkation of } \\
\text { metastases }\end{array}$ \\
\hline 2. E.P. & 59 & $\mathbf{F}$ & 4 & + & +- & - & - & - & $\begin{array}{l}\text { Abdominal pain } \\
\text { Weight loss }\end{array}$ & & Ileum & Liver & Resection of primary \\
\hline 3. C.U. & 46 & $\mathbf{F}$ & 10 & - & - - & - & - & - & $\begin{array}{l}\text { Abdominal pain } \\
\text { Fatigue }\end{array}$ & & Pancreas & Liver & $\begin{array}{l}\text { Resection of primary } \\
\text { and debulkation of } \\
\text { metastases }\end{array}$ \\
\hline 4. C.S. & 61 & $\mathbf{M}$ & 18 & +- & ++ & + & + & - - & Abdominal pain & & Ileum & Liver & $\begin{array}{l}\text { Resection of primary } \\
\text { Intrahepatic FUDR }\end{array}$ \\
\hline 5. V.C. & 63 & F & 29 & +- & +- & - & - & - & & & Pancreas & Liver & $\begin{array}{l}\text { Resection of primary } \\
\text { STZ and 5FU }\end{array}$ \\
\hline 6. V.W. & 64 & F & 15 & +- & - - & - & - & & $\begin{array}{l}\text { Abdominal pain } \\
\text { Weight loss, } \\
\text { N/V }\end{array}$ & Hepatomegaly & $?$ & Liver & $5 F U$ \\
\hline 7. E.H. & 54 & $\mathbf{M}$ & 84 & - & ++ & - & + & - & Weight loss & Hepatomegaly & Ileum & Liver & $\begin{array}{l}\text { Resection of primary } \\
\text { Antihistamine }\end{array}$ \\
\hline 8. R.H. & 52 & $\mathbf{M}$ & 36 & + & -- & - & - & \pm & Weight loss & Hepatomegaly & Ileum & Liver & Resection of primary \\
\hline 9. E.S. & 80 & $\mathrm{~F}$ & 14 & + & - - & - & - & - & $\begin{array}{l}\text { Abdominal pain } \\
\text { Weight loss }\end{array}$ & $\begin{array}{l}\text { Abdominal mass } \\
\text { Hepatomegaly }\end{array}$ & $?$ & Liver & 5FU, Cyproheptadine \\
\hline 10. L.S. & 58 & $\mathbf{M}$ & 96 & +- & -- & - & + & - & $\begin{array}{l}\text { Weight loss } \\
\text { Proximal } \\
\text { muscle } \\
\text { weakness }\end{array}$ & Hepatomegaly & Ileum & Liver & $\begin{array}{l}\text { Resection of primary } \\
\text { Cytoxan, SFU, STZ }\end{array}$ \\
\hline 11. R.B. & 54 & M & 39 & + & +- & - & + & & $\begin{array}{l}\text { Abdominal pain } \\
\text { Jaundice }\end{array}$ & $\begin{array}{l}\text { Hepatomegaly } \\
\text { Splenomegaly }\end{array}$ & Ileum & Liver & Resection of primary \\
\hline 12. J.W. & 57 & $\mathbf{M}$ & 2 & +- & ++ & + & + & - & $\begin{array}{l}\text { Weight loss } \\
\text { Fatigue }\end{array}$ & Hepatomegaly & Ileum? & Liver & \\
\hline 13. E.B. & 64 & F & 5 & +- & - & - & - & \pm & $\begin{array}{l}\text { Abdominal pain } \\
\text { Weight loss }\end{array}$ & $\begin{array}{l}\text { Abdominal mass } \\
\text { Chylous ascites }\end{array}$ & Pancreas? & $\begin{array}{l}\text { Mesentry \& } \\
\text { Nodes }\end{array}$ & \\
\hline 14. B.M. & 70 & $\mathbf{M}$ & 96 & +- & +- & - & + & - & Weight loss & Hepatomegaly & Ileum & Liver & $\begin{array}{l}\text { Resection of primary } \\
\text { and debulkation of } \\
\text { metastases }\end{array}$ \\
\hline
\end{tabular}

${ }^{*} \mathrm{D}$ : diarrhea, F: flushing, W: wheezing, VL: valvular lesion, T: telangiectasia, D: dermatitis.

In addition to carcinoid symptoms, seven of the patients had abdominal pain, nine weight loss and patient 10 had severe proximal muscle weakness. All patients except case 13 had evidence of liver metastases on CT scan.

The primary site of the tumor was in the ileum in eight patients, in the pancreas in two, and in 4 it was not identified. In spite of laparotomy, due to extensive intraabdominal metastases, the primary site was not detected in case 9 and was suspected to be in the pancreas in case 13. Cases 6 and 13 did not have a laparotomy and the diagnosis was made by liver biopsy. Case 13 had a suspicious filling defect in the ileum on radiographic studies of the small bowel.

Ten patients had resection of their primary tumors and debulking of metastases and five patients had chemotherapy.
The biochemical features of our patients are shown in Table 2. Mean values for blood serotonin before and the last value(s) after SMS therapy are given. All of the patients except cases 3 and 14 had elevated blood serotonin levels. Case 3 had elevated ACTH as the only hormonal abnormality. She did not have any clinical or biochemical evidence of Cushing's syndrome. Two had diarrhea and the Verner Morrison (WDHAA) syndrome. Eight patients had elevated 24-hr urinary 5HIAA. Serum gastrin was elevated in two cases without evidence of ulcer disease and normal serum $B_{12}$ levels. Substance $P$ was elevated in cases 4,5 , and 8. VIP was raised in cases 5 and 6 . Both $\mathrm{C}$-terminal and $\mathrm{N}$-terminal PTH were elevated in case 9 , which in the presence of normal calcium and low vitamin D was suggestive of secondary hyperparathyroidism. There were no selection criteria as far 
VINIK AND MOATTARI

Table 2. Biochemical Features of Patients with Carcinoid Tumors

\begin{tabular}{|c|c|c|c|c|c|c|c|}
\hline \multirow{2}{*}{$\begin{array}{l}\text { Patients No. } \\
\text { and initials }\end{array}$} & \multicolumn{2}{|c|}{$\begin{array}{l}\text { Plasma serotonin } \\
(\mathrm{ng} / \mathrm{ml})\end{array}$} & \multicolumn{2}{|c|}{$\begin{array}{l}\text { Urinary } 5 \mathrm{HiAA} \\
\quad(\mathrm{mg} / 24 \mathrm{hr})\end{array}$} & \multirow{2}{*}{$\begin{array}{l}\text { Other hormonal } \\
\text { abnormalities }\end{array}$} & \multirow{2}{*}{$\begin{array}{l}\text { Dates of } \\
\quad \text { SMS } \\
\text { treatment }\end{array}$} & \multirow{2}{*}{$\begin{array}{c}\text { Maximum } \\
\text { SMS dosage } \\
(\mu g / \text { day })\end{array}$} \\
\hline & PreSMS & PostSMS & PreSMS & PostSMS & & & \\
\hline 1. J.B. & 2210 & 1642 & 78 & NL & & $12 / 84$ & 1000 \\
\hline 2. E.P. & 1125 & 2323 & $\mathrm{NL}^{*}$ & NL & Gastrin: 670 & $1 / 85$ & 600 \\
\hline 3. C.U. & 160 & 129 & NL & NL & ACTH: 2030 & $4 / 85$ & 300 \\
\hline 4. C.S. & 981 & 671 & 43 & NL & Sub. P: 99 & $7 / 85$ & 500 \\
\hline 5. V.C. & - & 391 & NL & NL & VIP: 158 , SubP: 105 & $9 / 85$ & 200 \\
\hline 6. V.W. & - & 372 & NL & NL & VIP: 668 & $9 / 85$ & 600 \\
\hline 7. E.H. & 1264 & 1278 & 245 & NL & & $7 / 86$ & 500 \\
\hline 8. R.H. & 3162 & 2157 & 118 & 195 & Substance P: 67 & $8 / 86$ & 500 \\
\hline 9. E.S. & 1246 & 1083 & NL & NL & PTH: 785, (Ca: 10) & 9/86 & 750 \\
\hline 10. L.S. & 2385 & 2345 & 112 & 94 & Gastrin: 536 & $11 / 86$ & 500 \\
\hline 11. R.B. & 1886 & 1903 & 394 & 40 & & $12 / 86$ & 1000 \\
\hline 12. J.W. & 2484 & 2290 & 144 & 127 & & $2 / 87$ & 750 \\
\hline 13. E.B. & 1595 & 1350 & NL & NL & & $3 / 87$ & 750 \\
\hline 14. B.M. & 132 & 124 & 49 & 22 & & $4 / 87$ & 300 \\
\hline
\end{tabular}

${ }^{*} \mathrm{NL}=$ normal.

as symptoms or extent of the disease. After written consent, the patients were admitted to the Clinical Research Unit of the University of Michigan Hospital from their initial studies and were then followed in the ambulatory care unit with periodic readmission to the Clinical Research Unit for evaluation of progress.

\section{CLINICAL AND PARACLINICAL EVALUATION}

After a complete history and physical exam, blood for electrolytes, renal and liver function tests, and complete cell count was drawn. Gastrointestinal hormones (gastrin, pancreatic polypeptide, vasoactive intestinal peptide, substance $P$, motilin) and whole blood serotonin were drawn every 4-6 hr for $24 \mathrm{hr}$ via an indwelling catheter before and after SMS 201-995 therapy. Gastrointestinal hormones were measured by previously described methods (21), and whole blood serotonin was done by SmithKline laboratories by a flurimetric method (28-30). Twenty-four-hour urines for 5HIAA (31) were collected before and $24 \mathrm{hr}$ after SMS therapy.

Serum prolactin, parathyroid hormone, cortisol, and ACTH were also measured. Small bowel perfusion studies (32) were done before and $1 \mathrm{hr}$ after $100 \mu \mathrm{g}$ subcutaneous injection of SMS 201-995 in six patients with diarrhea.

Patients with wheezing had pulmonary function tests before and one day after SMS 201-995 (100 $\mu \mathrm{g}$ BID). Patients with extra heart sounds, heart murmurs, or shortness of breath were evaluated by M-mode and 2-D echocardiogram for evidence of right-sided cardiac lesions. In one patient with an elevated ACTH value, metapyrone, low-dose and high-dose dexamethasone tests were performed. One patient with a severe proximal myopathy had an electromyogram done before and after recovery of muscle strength after treatment with SMS 201995.

\section{THERAPY}

SMS 201-995 (Sandoz, East Hanover, New Jersey) was started in an initial dosage of $100 \mu \mathrm{g}$ subcutaneously every $12 \mathrm{hr}$ and the dose was gradually increased to control symptoms and correct paraclinical abnormalities. The maximum maintenance dose that we used was $250 \mu \mathrm{g}$ every $6 \mathrm{hr}$.

\section{FOLLOW-UP}

After discharge from the hospital, patients kept a diary regarding the frequency and consistency (formed, soft, or watery) of their bowel movements and also episodes of flushing, which were graded for duration, extent and severity: (1) face only, (2) face and upper extremities, (3) face and upper extremities and a rise in pulse rate and/or a decrease in blood pressure, and (4) whole body and a decrease in blood pressure.

The patients were followed in the outpatient clinic with regular physical examinations, total blood count, serum electrolytes, renal and liver functions and measurement of gastrointestinal hormones and total blood serotonin every six weeks. Twenty-four-hour urines for 5HIAA, CT of abdo- 
Table 3. Clinical and Biochemical Responses to SMS 201-995 THERAPY*

\begin{tabular}{cccccc}
\hline Case & Diarrhea & Flushing & Wheezing & $\begin{array}{c}\text { Urinary } \\
\text { 5HIAA }\end{array}$ & $\begin{array}{c}\text { Blood } \\
\text { serotonin }\end{array}$ \\
\hline 1 & $\mathrm{R}$ & $\mathrm{R}$ & - & $\mathrm{R}$ & $\mathrm{N}$ \\
2 & $\mathrm{R}$ & $\mathrm{R}$ & - & - & $\mathrm{W}$ \\
3 & - & - & - & - & - \\
4 & $\mathrm{R}$ & $\mathrm{R}$ & $\mathrm{R}$ & $\mathrm{R}$ & $\mathrm{N}$ \\
5 & $\mathrm{R}$ & $\mathrm{R}$ & - & - & $?$ \\
6 & $\mathrm{R}$ & - & - & - & $?$ \\
7 & - & $\mathrm{R}$ & $\mathrm{R}$ & $\mathrm{R}$ & $\mathrm{N}$ \\
8 & $\mathrm{P}$ & $\mathrm{R}$ & - & $\mathrm{W}$ & $\mathrm{P}$ \\
9 & $\mathrm{~N}$ & - & - & - & $\mathrm{N}$ \\
10 & $\mathrm{P}$ & - & - & $\mathrm{P}$ & $\mathrm{N}$ \\
11 & $\mathrm{~N}$ & $\mathrm{R}$ & - & $\mathrm{R}$ & $\mathrm{N}$ \\
12 & $\mathrm{P}$ & $\mathrm{P}$ & $\mathrm{R}$ & $\mathrm{N}$ & $\mathrm{N}$ \\
13 & $\mathrm{R}$ & - & - & - & $\mathrm{N}$ \\
14 & $\mathrm{R}$ & $\mathrm{R}$ & - & $\mathrm{P}$ & - \\
\hline
\end{tabular}

*R: response (more than $75 \%$ improvement); P: partial response (25-75\% improvement); $\mathrm{N}$ : no response (less than $25 \%$ improvement); W: worsening (more than $125 \%$ of initial values); -; No symptoms or normal values; ?: Pre-SMS values are not available.

men, and pulmonary function tests in those with wheezing were repeated every three months.

The patients received supplements of pancreatic enzymes whenever steatorrhea was present either before SMS therapy or if changes in bowel habit developed suggestive of malabsorption after SMS therapy. SMS was continued as long as the patients wished to receive treatment and had evidence of clinical or biochemical improvement. Patients who showed no response after six months of treatment were referred for consideration of chemotherapy.

\section{EVALUATION OF RESPONSES TO SMS 201-995}

The clinical and biochemical responses of individual cases are shown in Table 3 . The responses to therapy were divided into four groups. (1) Responders were those with more than $75 \%$ improvement, ie, a $75 \%$ drop in the frequency or intensity of a symptom or $75 \%$ drop in the level of a biochemical marker. (2) Partial responders were those with 25 75\% improvement. (3) Nonresponders were those with less than $25 \%$ improvement. (4) Worsening
TABLE 5. EFFECTS OF SMS 201-995 ON GaStroENTEROPANCREATIC HORMONES $(\mathrm{pg} / \mathrm{ml})^{*}$

\begin{tabular}{lrrrrrr}
\hline & Gastrin & SRIF & VIP & hPP & Motilin Sub P \\
\hline Patient M.T. & & & & & & \\
Before treatment & 33 & 79 & $<10$ & 139 & 139 & $<10$ \\
Week 2 & 20 & 41 & $<10$ & 87 & 46 & $<10$ \\
Week 4 & 13 & 85 & $<10$ & & 50 & \\
Month 2 & 20 & 185 & $<10$ & 15 & 17 & \\
Month 3 & 10 & 170 & $<10$ & 14 & & \\
Patient D.B. & & & & & & \\
Before treatment & 36 & 73 & $<10$ & 59 & 119 & $<10$ \\
Week 2 & 20 & 76 & $<10$ & & 28 & \\
Week 4 & 30 & & $<10$ & 100 & & \\
Month 2 & 25 & 78 & $<10$ & 50 & 108 & \\
Month 3 & 46 & 122 & 10 & 33 & 93 & $<10$ \\
Month 4 & 22 & 125 & $<10$ & 63 & 48 & \\
Patient J.M. & & & & & & \\
Before treatment & 50 & 324 & 25 & 372 & 521 & $<10$ \\
Week 2 & 29 & & $<10$ & 32 & & $<10$ \\
Week 4 & 37 & 252 & 21 & 84 & 323 & $<10$ \\
Month 2 & 37 & 330 & 17 & 107 & 412 & $<10$ \\
Month 3 & 19 & 446 & $<10$ & 91 & 412 & $<10$ \\
Month 4 & 13 & 634 & 23 & 102 & & \\
Normal range & $<150$ & $<150$ & $<25$ & $<1000$ & $<400$ & $<10$ \\
\hline
\end{tabular}

*SRIF: somatostatin; subP: substance P.

†SMS, $50 \mu \mathrm{g} /$ day for two weeks.

†SA twice daily for two weeks.

was judged to occur if the clinical and/or biochemical values increased by more than $25 \%$ of their initial estimation. The overall responses of the patients to SMS 201-995 are shown in Table 4.

\section{Flushing}

Our patients were a heterogenous group with advanced carcinoid tumors refractory to conventional chemotherapeutic agents, who were tried on the somatostatin analog with variable clinical and biochemical responses. We have previously shown a dramatic response of flushing as a symptom to treatment with somatostatin (33). Frohlich and colleagues (34) have also reported on the value of native somatostatin given by continuous infusion as a means of reversing the pentagastrin-induced flushing in carcinoid patients. We, however, were unable to show that pentagastrin was a reliable means whereby flushing could be provoked in our

Table 4. Clinical and Biochemical Responses in 14 Patients with Carcinoid Syndrome

\begin{tabular}{lccccc}
\hline & Diarrhea & Flushing & Wheezing & $\begin{array}{c}\text { Urinary } \\
\text { 5HIAA }\end{array}$ & $\begin{array}{c}\text { Blood } \\
\text { serotonin }\end{array}$ \\
\hline Responders & $7(58 \%)$ & $8(89 \%)$ & $3(100 \%)$ & $4(50 \%)$ & 0 \\
Partial responders & $3(25 \%)$ & $1(11 \%)$ & 0 & $2(25 \%)$ & $1(10 \%)$ \\
$\begin{array}{l}\text { Nonresponders } \\
\text { Worsening } \\
\quad \text { No. of patients } \\
\quad(\% \text { of total patients) }\end{array}$ & 0 & 0 & 0 & $1(12 \%)$ & $8(80 \%)$ \\
$\quad 12(17 \%)$ & 0 & 0 & $1(12 \%)$ & $1(10 \%)$ \\
\hline
\end{tabular}



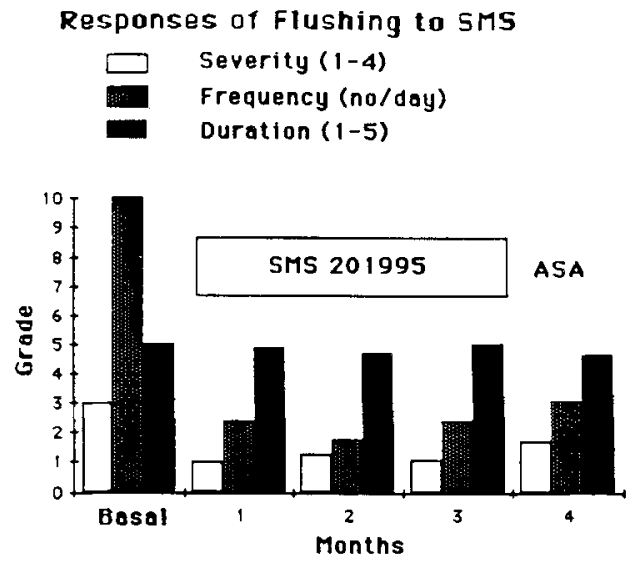

Fig 4. Responses of fushing to somatostatin analog treatment. Frequency is markedly improved as well as intensity, but duration is unaffected.

patients. Kvols et al (35) found that 19 of 24 patients with carcinoid tumors had a $50 \%$ reduction in flushing, three a minor response and in two patients the drug failed. Richter et al (36) showed that six of eight patients had improved symptoms. Our more recent experience is that $90 \%$ of our patients presented with flushing as their major symptom. In all instances, the symptom complex improved with a clear decrease in the frequency of symptoms with doses of $1-2 \mu \mathrm{g} / \mathrm{kg} / \mathrm{day}$. In no instance was there resistance to the drug, tachyphyllaxis did not occur, and withdrawal of the drug or substitution with distilled water was always followed by recurrence of the symptom complex. In contrast to another study (36), relapse of flushing did not occur with continued treatment once it was under control. However, in contrast to the reduction in number of episodes, the severity decreased only slightly and the duration of each episode was essentially unchanged (Figure 4).

In order to determine the mechanism whereby flushing was reduced, we admitted patients to the Clinical Research Unit and monitored episodes of flushing without treatment for a 48 -hr period and
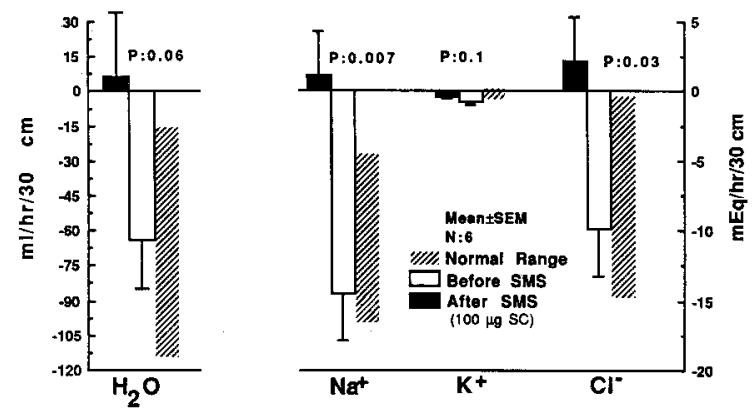

Fig 5. The effects of somatostatin analog treatment on small intestinal transport of water and electrolytes in 6 patients with secretory diarrhea.

again after treatment with somatostatin for a further $48 \mathrm{hr}$. Blood samples were drawn every $4 \mathrm{hr}$ to estimate the levels of vasoactive compounds. Table 5 shows examples in which almost all the measured hormones were suppressed by the administration of SMS 201-995, save for endogenous somatostatin which paradoxically rose with treatment. This may suggest that binding of SMS 201-995 to receptors on the tumors and the vascular smooth muscle causes displacement of endogenous somatostatin and, thus, results in a rise in the circulating level. What the consequence of this event is remains to be determined.

The extreme example of flushing is the carcinoid crisis with a profound fall in blood pressure. It is deemed unwise to submit a patient to anesthesia or operation without premedication with a combination of adrenergic blocker, steroids, thorazine, and aspirin. Kvols et al (37) has presented data on one such patient who, soon after induction of anesthesia, had a fall in blood pressure unresponsive to intravenous fluid, calcium, neosynephrine, or epinephrine administration. Within $1 \mathrm{~min}$ of $100 \mu \mathrm{g}$ of SMS 201-995 given intravenously, blood pressure rose and the patient made an uneventful recovery.

Thus, while the mechanism of action of SMS 201-995 and the factors mediating flushing and va-

Table 6. SMS 201-955 Effects on Pulmonary Function Tests in Two Carcinoid Patients with Wheezing*

\begin{tabular}{|c|c|c|c|c|c|c|c|c|c|c|c|c|}
\hline \multirow[b]{2}{*}{ Case } & \multicolumn{2}{|c|}{$F V C$} & \multicolumn{2}{|c|}{$F E V-I$} & \multicolumn{2}{|c|}{$F E F(25-75 \%)$} & \multicolumn{2}{|c|}{$T L C R V$} & \multicolumn{2}{|c|}{$D L C o$} & \multirow[b]{2}{*}{ Pre } & \multirow[b]{2}{*}{ Post } \\
\hline & Pre & Post & Pre & Post & Pre & Post & Pre & Post & Pre & Post & & \\
\hline \multirow[t]{2}{*}{ 7(E.H.) } & 3.86 & 4.89 & 2.42 & 3.45 & 1.46 & 2.4 & 9.31 & 8.76 & 5.08 & 3.75 & 31.2 & 34.7 \\
\hline & $81 \%$ & $103 \%$ & $71 \%$ & $101 \%$ & $31 \%$ & $51 \%$ & $139 \%$ & $130 \%$ & $222 \%$ & $164 \%$ & $88 \%$ & $85 \%$ \\
\hline \multirow[t]{2}{*}{ 12(J.W.) } & 3.06 & 4.48 & 1.04 & 1.74 & 0.43 & 0.63 & 11.03 & 9.5 & 7.55 & 5.05 & 25.5 & 30.3 \\
\hline & $59 \%$ & $87 \%$ & $29 \%$ & $48 \%$ & $9 \%$ & $13 \%$ & $149 \%$ & $128 \%$ & $298 \%$ & $200 \%$ & $67 \%$ & $79 \%$ \\
\hline
\end{tabular}

*FVC: force vital capacity; FEV-1: force expiratory volume in one second; FEF: force expiratory flow; TLC: total lung capacity; RV: residual volume; DLCo: diffusion capacity; Pre: before SMS 201-995; Post: after SMS 201-995. 


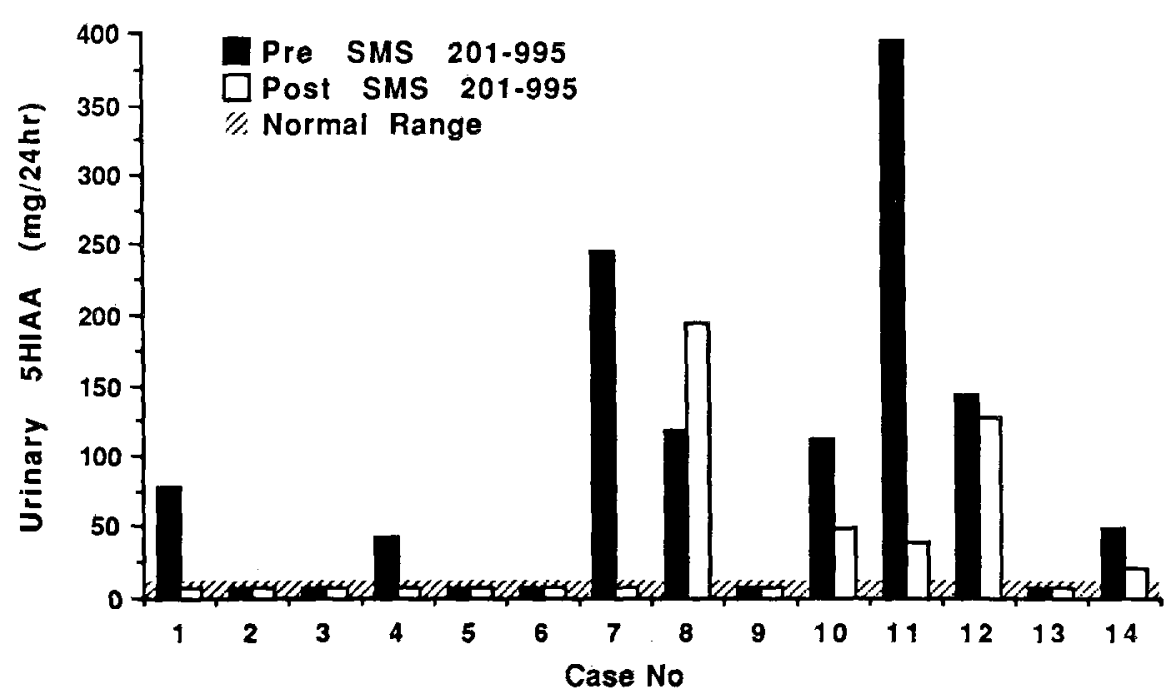

Fig 6. Urinary 5 hydroxyindoleacetic acid (5HIAA) responses to somatostatin analog in individual patients.

sodilatation are not yet clear, there can be no doubt that SMS 201-995 is a potent antidote to the vasoactive humors participating in the flush and hypotension. The drug may prove to be a useful adjunct in the preparation of patients for operative procedures and as a standby for the management of carcinoid crises.

\section{Responses of Diarrhea}

Diarrhea occurred in $86 \%$ of our patients and responded variably to SMS. The acute effect of SMS on water and electrolyte transport in six patients with diarrhea is shown in Figure 5. The overall pattern changed from a secretory to an absorptive state. Acute administration of SMS thus normalized the water and electrolyte transport across the proximal intestine, as has been shown in

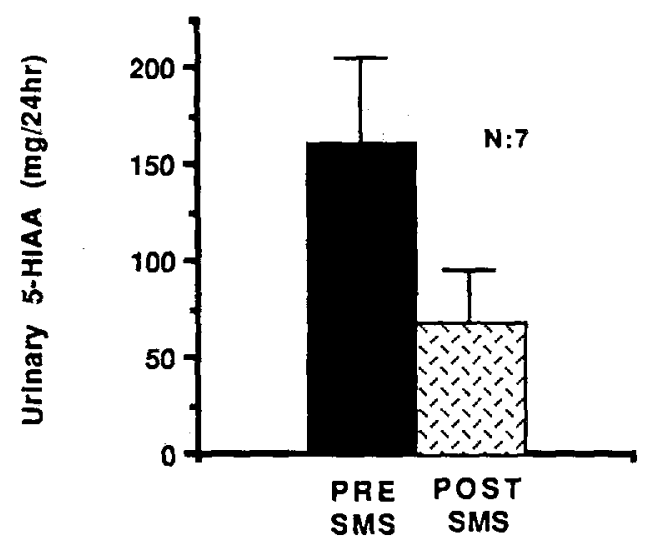

Fig 7. Mean \pm SD urinary 5HIAA responses to somatostatin analog (SMS). $P<0.05$. patients with WDHH syndrome $(38,39)$. The acute reduction in electrolyte secretion did not, however, predict the long-term response of diarrhea to SMS therapy, but this needs to be further examined in a larger number of patients. Only $44 \%$ of our patients with diarrhea had complete remission, a finding that differs from the improvement in 19/25 patients reported by Kvols et al (35). This could be due to the fact that diarrhea in patients with carcinoid tumors has multiple etiologies, ie, secretory, increased motility, malabsorption, partial luminal lymphatic obstruction, bacterial overgrowth, and short bowel syndrome due to surgical resection. The diarrhea may even appear to worsen with the appearance of steatorrhea, and the physician is not infrequently

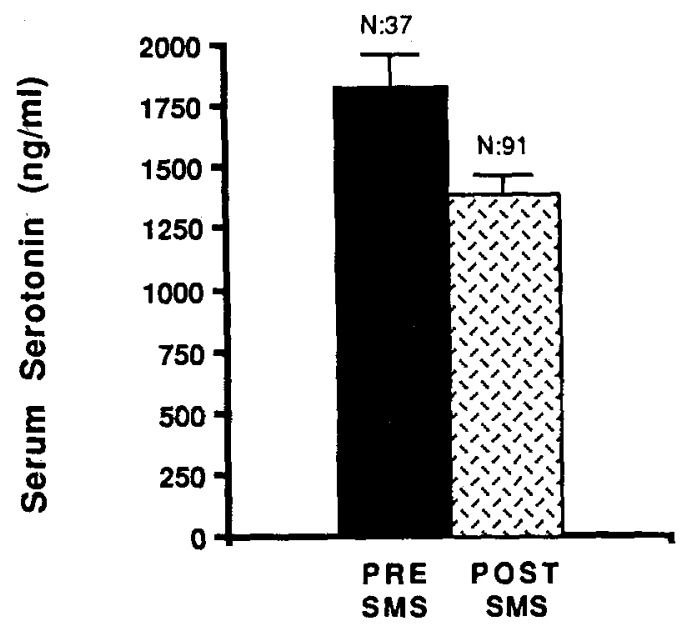

Fig 8. Mean \pm SD serum serotonin values before and after treatment with the analog. $P=N S$. 

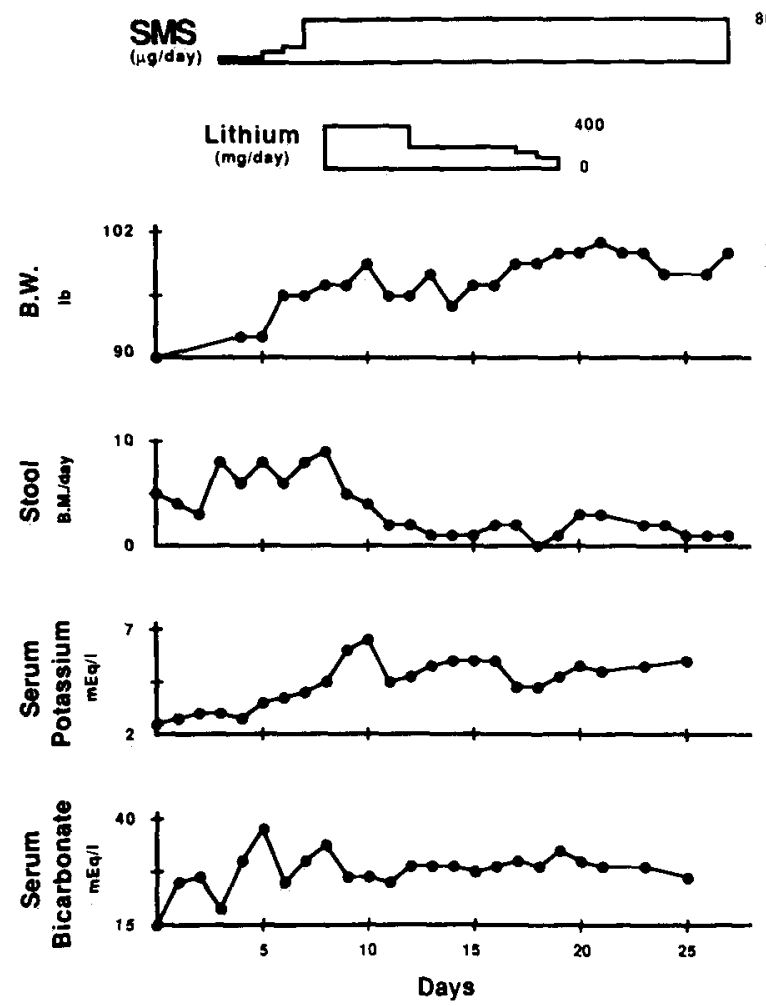

Fig 9. Responses to treatment of a patient with secretory diarrhea due to metastatic carcinoid secreting VIP.

faced with the confounding situation of not knowing to what to attribute the symptom. However, although somatostatin does inhibit exocrine pancreatic secretion (40), addition of pancreatic enzyme supplementation has not uniformly decreased SMSinduced steatorrhea (41). We did not find any consistent changes in frequency or consistency of bowel movements in response to pancreatic supple-

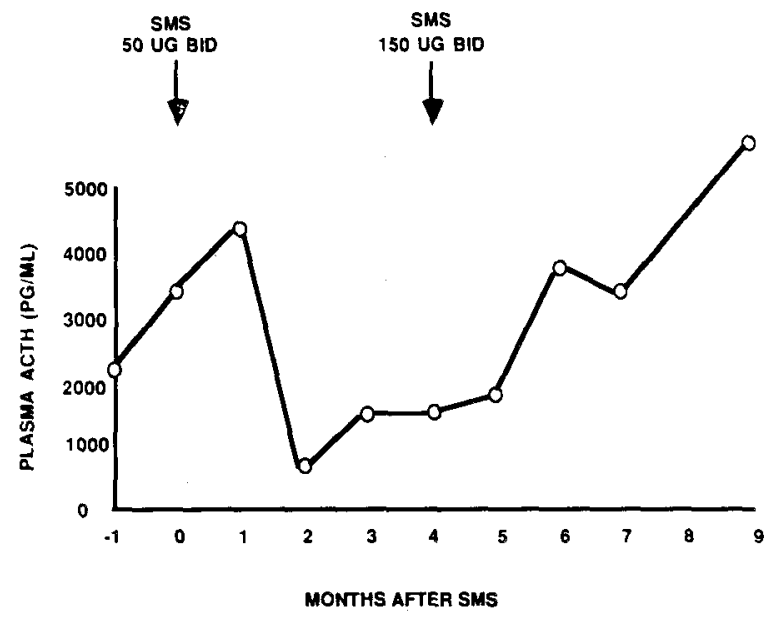

Fig 11. Malignant carcinoid, failure of response of ACTH to SMS despite tumor shrinkage (Fig. 10).

ment in those patients with steatorrhea before treatment or in the bowel habits after therapy with SMS 201-995, compatible with the notion that the steatorrhea has a complex pathogenesis and may be contributed to by alterations in bile flow, the direct effects of somatostatin on nutrient absorption, and intestinal motility (42).

The significant improvement in water and electrolyte transport across the small intestine after the initial dose of SMS without significant changes in blood serotonin implies a direct effect of SMS on the target organ independent of serotonin mediation (43).

\section{Effects of SMS on Pulmonary Function}

All three of our patients with wheezing had clinical improvement, and spirometric improve-

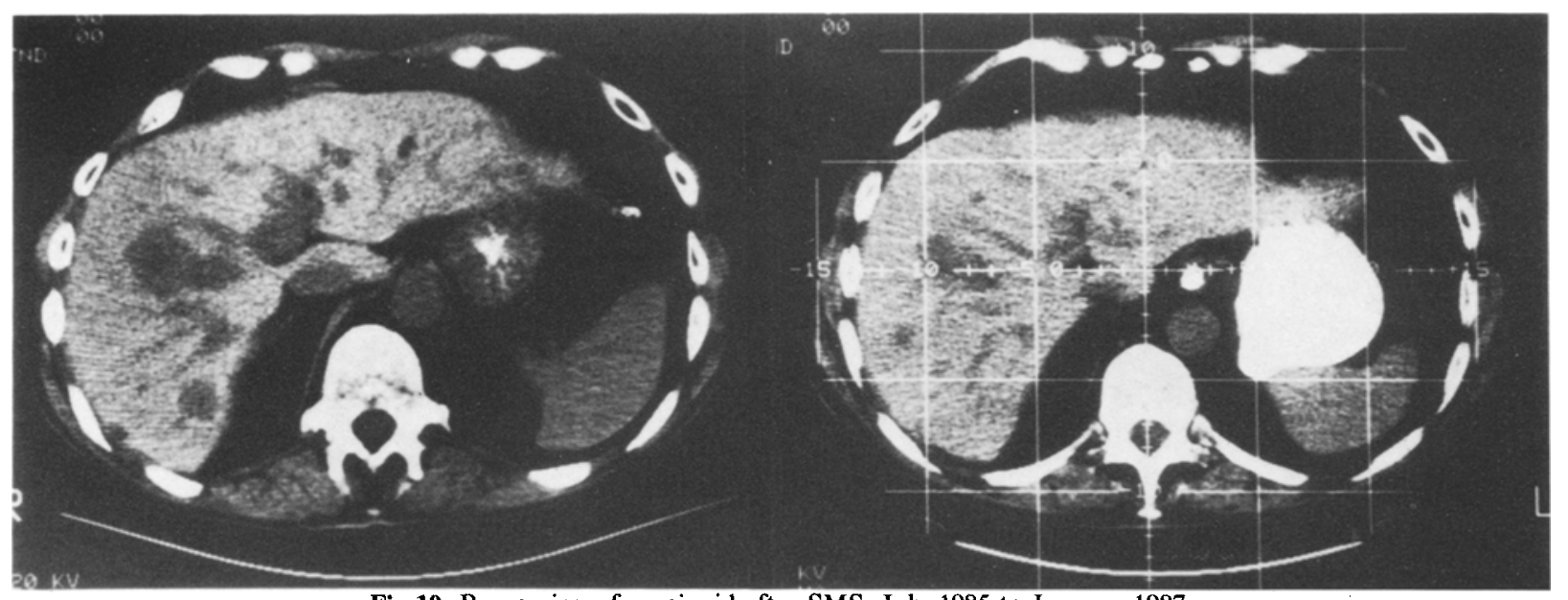

Fig 10. Regression of carcinoid after SMS, July 1985 to January 1987. 


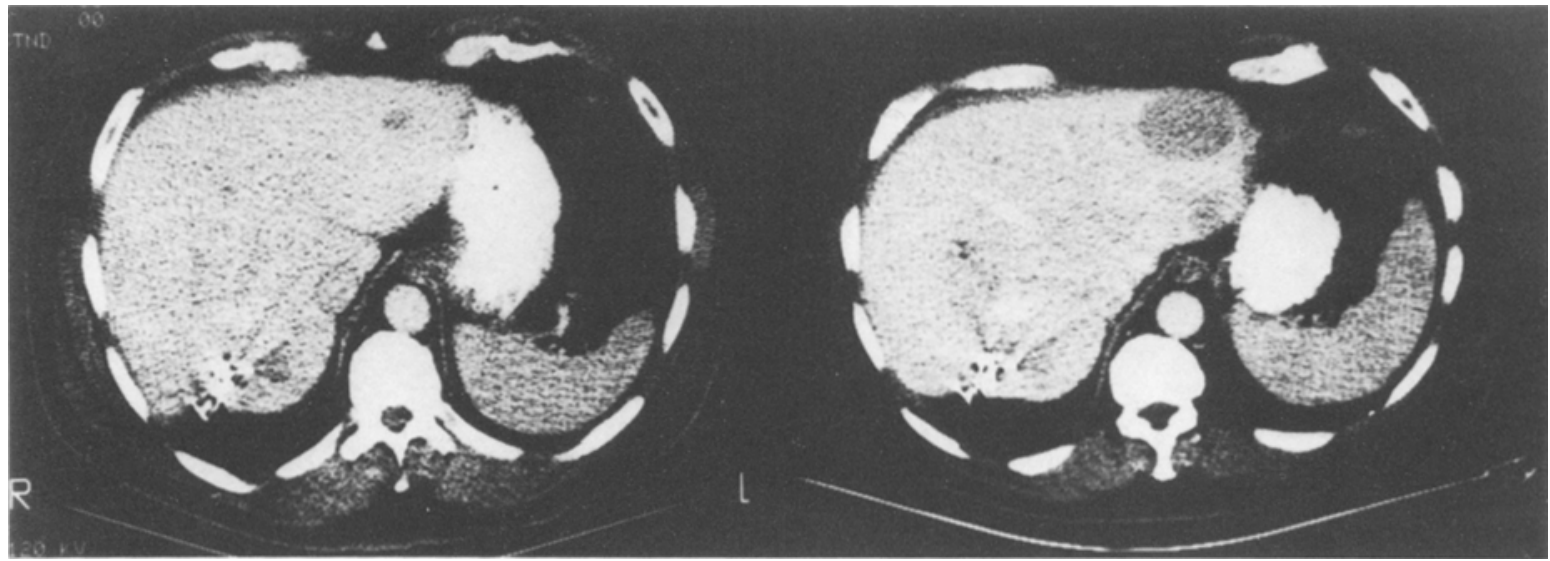

Fig 12. Progression of carcinoid after SMS, December 1984 to August 1986.

ment was documented (Table 6). Pulmonary function did not improve further after three months of treatment, indicating an irreversible component or small airway disease secondary to long-standing smoking.

\section{Effects of SMS on Myopathy}

Patient 10 in our series presented with severe proximal muscle weakness, with normal muscle enzymes and nerve conduction studies but electromyographic features of a proximal myopathy. Although a neurological deficit secondary to metastatic carcinoid has been seen (44), metabolicinduced neuromuscular disease is very rare (4547). Although our patient had a history of hypo-

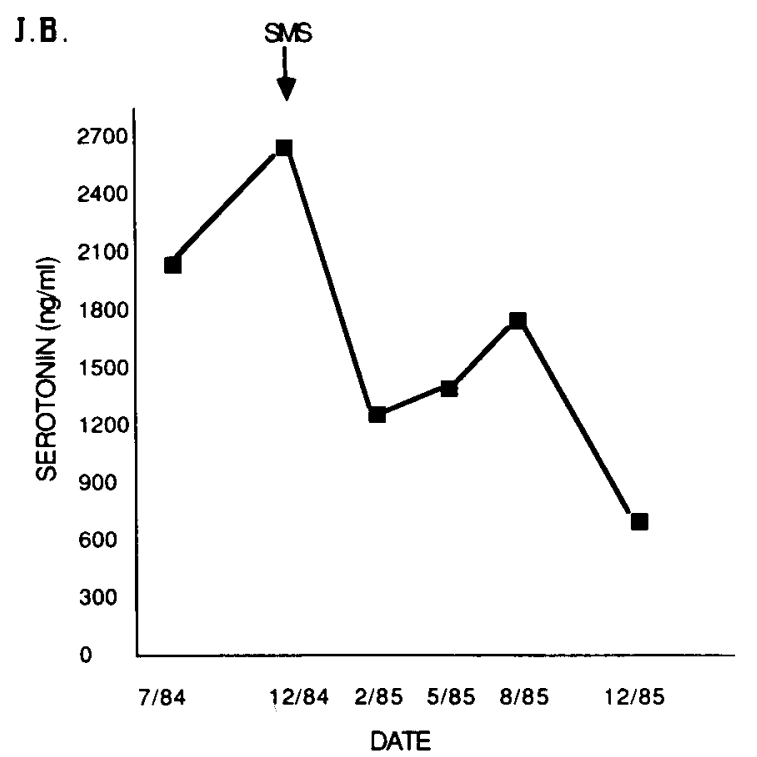

Fig 13. Progressive reduction in blood serotonin levels despite progression of tumor growth (Fig. 12). kalemia, at the time of admission his potassium was normal with no biochemical evidence of thyrotoxicosis, ectopic ACTH production, or osteomalacia. We believe that his severe myopathy was due to his carcinoid, although it might have been aggravated by severe diarrhea, weight loss, and poor nutrition. Histological changes can be induced in skeletal muscle of mice by intraperitoneal injection of 5HT (48). Three months after SMS therapy, the patient did not have any clinical evidence of myopathy with improvement in electromyographic features.

\section{Biochemical Responses}

There are conflicting reports regarding the biochemical responses of carcinoid patients to somatostatin. Richter et al (36) reported a significant drop in 5HT in eight patients treated with $150 \mu \mathrm{g} /$ day of SMS 201-995, but no changes in urinary 5HIAA, while others have found a drop in urinary 5HIAA (43). In prolonging treatment of four of their patients to 15-30 weeks, blood serotonin remained unchanged (41). In our patients, urinary 5HIAA dropped in almost all patients and normalized in one third of the patients. Figure 6 compares the urinary 5HIAA before SMS therapy with the most recent values after therapy. Three of eight patients normalized their 24-hr 5HIAA. In case 8 urinary 5HIAA initially dropped but subsequently rose. The overall post-SMS 24-hr urinary 5HIA was significantly lower than basal values $(P<0.05)$ (Figure 7).

The blood serotonin levels during the course of therapy are shown in Figure 8. Although few of our patients had a fall in their blood serotonin level, the overall post-SMS values were not significantly lower than pretreatment values. 


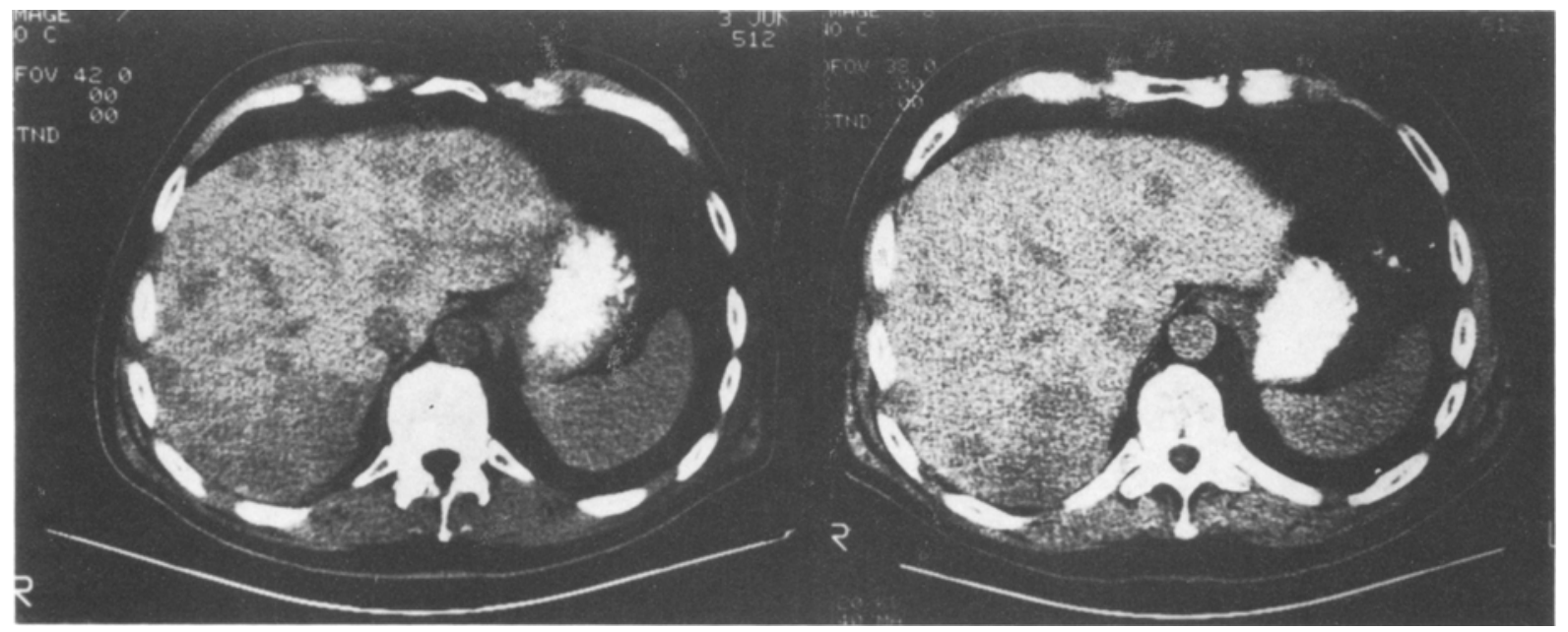

Fig 14. Lack of progression of carcinoid after SMS, June 1986 to March 1987.

There was no clinical correlation between clinical responses and either the urinary 5HIAA or the blood serotonin levels. This may reflect the fact that there are multiple etiologic factors involved in the symptomology of carcinoid tumors. In our patients, those who responded clinically required no more than $500 \mu \mathrm{g} /$ day to control their symptoms, although we have examined the response to higher doses in certain instances.

\section{Responses of Tumor Growth and Metastases}

Due to the slow growth of carcinoid tumors, it is difficult to assess the effect of SMS on the rate of tumor growth or regression. Shrinkage of liver metastases in patients with carcinoids $(35,39)$ and other functioning pancreatic neuroendocrine tumors (49) has been reported. We have had variable experiences. Patient 6 was seen in 1980 with watery diarrhea two to three times per day, vomiting after meals, and weighed $140 \mathrm{lb}$. A diagnosis of spastic colon was made. In May 1984, CT showed an enlarged liver, which was shown to be an adenocarcinoma on biopsy in January 1985 , for which she received four months of chemotherapy with 5fluorouracil. After four months she had a perforated gastric ulcer, and laparotomy biopsy revealed a

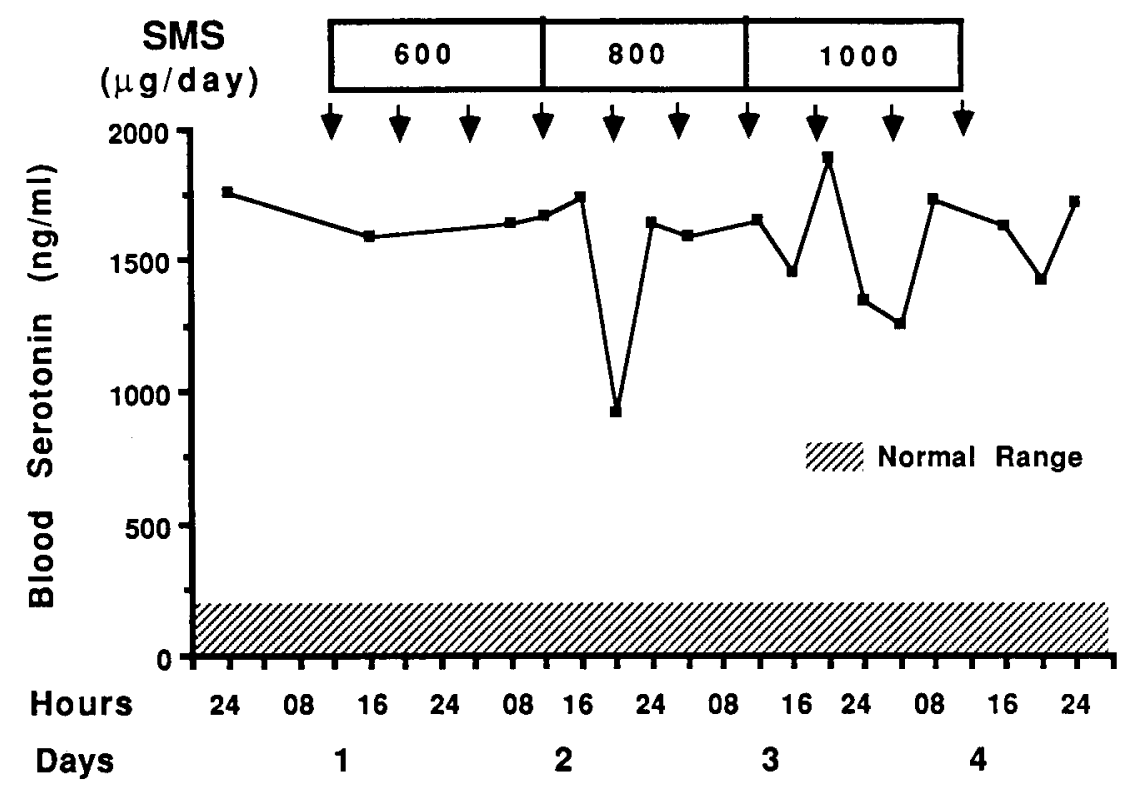

Fig 15. Failure of increasing doses of SMS to alter blood serotonin values despite inhibition of tumor growth (Fig. 14). 
metastatic carcinoid tumor. VIP levels postoperatively were found to be in the $>1000 \mathrm{pg} / \mathrm{ml}$ region (normal $<150 \mathrm{pg} / \mathrm{ml}$ ). In September 1985 , she was seen at the University of Michigan and was found to have almost complete replacement of the right lobe of the liver with metastases and had lost $45 \mathrm{lb}$ weight. Initiation of SMS treatment resulted in cessation of diarrhea (Figure 9). Six months later she presented with severe right upper quadrant pain, CT showed infarction of the tumor, and VIP levels had returned to the near normal range.

The relationship between tumor size and growth and the biochemistry is not a simple one. Figure 10 shows a patient in whom the tumor is clearly shrinking, but ACTH levels have risen to the 2000$3000 \mathrm{pg} / \mathrm{ml}$ range (Figure 11). On molecular sieve chromatography, the ACTH coeluted with native ACTH but, the patient has no clinical features of Cushing's, is gaining weight, and has no diarrhea or flushing. Figure 12 illustrates progression of tumor growth after 18 months of SMS therapy, yet there has been a dramatic fall in blood serotonin values (Figure 13), and the patient is entirely asymptomatic. Figure 14 illustrates the opposite situation of unchanged tumor size, a very well patient and hormonal levels that were unaffected by SMS even in doses as high as $1000 \mu \mathrm{g} /$ day (Figure 15).

We have follow up CT in 10 patients. Cases 4 and 6 showed some regression of the tumor, in case 6 it infarcted. Cases 1, 2, 9, and 11 showed progression, and cases $3,5,7,8$, and 10 showed no changes on the CT scan followed for up to two years. Currently, we are using higher doses of SMS to see if we can suppress all biochemical markers and also tumor growth.

\section{Incidence and Nature of Side Effects}

No major clinical side effects have been observed in our patients. Initially, during injection of somatostatin a few patients experienced a burning sensation at the site of injection that improved with slow injection of the drug. A few patients had nausea and/or light-headedness immediately after injection lasting up to $30 \mathrm{~min}$ that gradually faded with repeated injection. We have also had one patient present with acute calculous cholecystitis after two years of treatment with SMS, but retrospective analysis revealed the presence of gallstones on CT done before the advent of SMS treatment. We have also observed that steatorrhea seems to occur in a dose-dependent manner. With doses greater than $500 \mu \mathrm{g} / \mathrm{day}$, steatorrhea is almost universal, but as mentioned above, does in some instances respond to pancreatic enzyme supplements.

\section{SUMMARY}

We have reviewed the literature on current therapy of carcinoid patients with special emphasis on the use of SMS 20-1995. In addition, we present data on the effects of SMS 201-995 on clinical and biochemical indices and tumor growth. Diarrhea is abolished or significantly reduced in $83 \%$ of patients, flushing improves in $100 \%$, wheezing improved in $100 \%$ with a decrease in airways resistance, and in one patient myopathy has improved. Blood serotonin is notoriously resistant to intervention, and urinary 5HIAA will decrease marginally in $75 \%$ of cases. Tumors, in general, continue to grow, but this may be slowed or in rare cases tumor growth is arrested. In individual instances the tumor may even infarct, leading to spontaneous cure.

Short of an effective curative or palliative agent, SMS can control flushing and wheezing in most and diarrhea in some patients with carcinoid tumors with improvement of their general condition. The effects of SMS on tumor growth needs to be further evaluated in relation to the slow progression and indolent nature of these tumors. Since little effective therapy is available and much may be harmful, it seems not unreasonable to offer SMS 201-995 for the control of symptoms and for palliation at this point in time. Limits of safe and effective dosage need to be established and long-term follow-up is a prerequisite to defining the ultimate role of this form of peptide therapy in the carcinoid syndrome.

\section{REFERENCES}

1. Davis Z, Moertel CG, Mclirath DC: The malignant carcinoid syndrome. Surg Gynec Obstet 137:637-644, 1973

2. Buchanan KD, Johnston CF, O'Hare MMT, et al: Neuroendocrine tumors. A European view. Am J Med 81 (Suppl 6b): 14-22, 1986

3. Solcía E, Capella C, Buffa R, Frigerio B, Usellini L, Fiocca $\mathrm{R}$ : Morphological and functional classification of endocrine cells and related growths in the gastrointestinal tract. In Gastrointestinal Hormones, GBJ Glass (ed). New York, Raven Press, 1988, pp 1-17.

4. Weil C: Gastroenteropancreatic endocrine tumors. Klivo 63: 433-459, 1985

5. Simpson S, Vinik AI, Marangos PJ, Lloyd RV: Immunohistochemical localization of neuron-specific enolase in gastroentero-pancreatic neuroendocrine tumors. Correlation 
with tissue and serum levels of neuron-specific enolase. Cancer 54:1364, 1984

6. Moertel CG: Treatment of the carcinoid tumor and the malignant carcinoid syndrome. J Clin Oncol 1:727-740, 1983

7. Godwin JD II: Carcinoid tumors an analysis of 2837 cases. Cancer 36:560-569, 1975

8. Strodel W,Vinik A, Thompson N, et al: Carcinoid tumors of the small intestine. In Endocrine Surgery Update. NW Thompson, AI Vinik (eds). New York, Grune \& Stratton, 1983, pp 293-320

9. Melmon KL, Sjoerdsma A, Oates JA, Laster L: Treatment of malabsorption and diarrhea of carcinoid syndrome with methysergide. Gastroenterology 48:18, 1965

10. Feldman JM: Urinary serotonin in the diagnosis of carcinoid tumor. Clin Chem 32:840-844, 1986

11. Sandler M, Karim SMM, William ED: Prostaglandin in amine-peptide-secreting tumors. Lancet 2:1053-1055, 1968

12. Alumets J, Hakanson R, Ingemannson S, Sundler F: Substance $\mathrm{P}$ and 5-HT in granules isolated from an intestinal argentaffin carcinoid. Histochemistry 52:217, 1977

13. Oates JA, Pettinger WA, Doctor RB: Evidence for the release of bradykinin in the carcinoid syndrome. J Clin Invest 45:173-178, 1966

14. Pernow B, Waldenstrom J: Determination of 5-hydroxytryptamine, 5 hydrosyindolacetic acid and histamine in thirtythree cases of carcinoid tumor (argentaffinoma). Am J Med $34: 255-260,1985$

15. Wilander E, Grimelius L, Portela-Gomes G, Sloan JM: Substance $\mathbf{P}$ and enteroglucagon-like immunoreactivity in argentaffin and argyrophil mid gut carcinoid tumors. Scand J Gastroenterol (suppl) 14:19-25, 1979

16. Strodel WE, Vinik AI, Jaffe BM, Eckhauzer F, Thompson NW: Substance $P$ in the localization of a carcinoid tumor. J Surg Oncol 27:106-111, 1984

17. Lucas KG, Feldman JM: Flushing in the carcinoid syndrome and plasma kallikrein. Cancer 58:2290-2293, 1986

18. Pernow B, Waldenstrom J: Determination of 5-hydroxytryptamine, 5-hydroxy indoleacetic acid and histamine in 33 cases of carcinoid (argentaffinoma). Am J Med 23:16-25, 1957

19. Feldman JM: Increased dopamine production in patients with carcinoid tumors. Metabolism 34:255-260, 1985

20. Theodrosson-Norheim E, Norheism KO, Brodin E, et al: Neuropeptide K: A major tachykinin in plasma and tumor tissues from carcinoid patients. Biochem Biophys Res Commun 131:77-83, 1985

21. Vinik AI, Strodel WM, Lloyd RV: Unusual gastroenteropancreatic tumors and their hormones. In Endocrine Surgery Update. NW Thompson, AI Vinik (eds). New York, Grune \& Stratton, 1983, pp 293-320

22. Feldman J, O'Dorisio TM: Role of neuropeptides and serotonin in the diagnosis of carcinoid tumors. Am J Med 81(suppl 6b):41-48, 1986

23. Kvols LK: Metastatic carcinoid tumors and the carcinoid syndrome. A selective review of chemotherapy and hormonal therapy. Am J Med 81 (suppl 6b):49-55, 1986

24. Maton PN, Camilleri M, Griffin G, Hodgson H, Allison DJ, Chadwick VS: The role of hepatic arterial embolization in the carcinoid syndrome. Br Med J 287:932-935, 1983

25. Gyn NE, Kayasseh L, Keller IJ: VIP and watery diarrhea. In Gut Hormones, 2nd ed. SR Bloom, JM Polak (ed). Edinburgh, Churchill Livinston, 1981, pp 581-585
26. Sheppard M, Shapiro B, Primstone B, Kronhein S, Berelowitz M, Gregory M: Metabolic clearance and plasma halfdisappearance time of exogenous somatostatin in man. J Clin Endocrinol Metab 48:50-53, 1979

27. Bauer W, Briner U, Doepfner W, Waller R, Huguenin R, Marbach P, Fletcher TJ, Pless T: A very potent and selective octapeptide analogue of somatostatin with prolonged action. Life Sci 31:1133-1140, 1982

28. Walker TP: The determination of serotonin (5-hydroytryptamine) in human blood. J Lab Clin Med 55:824-829, 1959

29. Davis RB: The concentration of serotonin in normal human serum as determined by an improved method. J Lab Clin Med 54:344-351, 1959

30. Das ML: A rapid, sensitive method for direct estimation of serotonin in whole blood. Biochem Med 6:299-309, 1972

31. Udenfriend $\mathrm{C}$, Titus $\mathrm{E}$, Weissbach $\mathrm{H}$ : The identification of 5-hydroxy-3-indoleacetic acid in normal urine and a method for its assay. J Biol Chem 216:499-505, 1955

32. Vinik AI, Achem Karam S, Owyang C: Gastrointestinal hormones in clinical medicine. In Special Topics in Endocrinology and Metabolism, Vol 4. MP Cohen, PP Foa (eds). New York. Alan R. Liss, 1982, pp 93-138

33. Tsai ST, Lewis E, Vinik AI: The use of a somatostatin analogue in the management of the flushing syndrome. Scand J Gastroenterol 21(suppl 119):267-274, 1985

34. Frohlich J, Bloomgarden Z, Oates J, et al: The carcinoid flush provocation by pentagastrin and inhibition by somatostatin. N Engl J Med 299:1055-1057, 1978

35. Kvols LK, Moertel CG, O'Connell MJ, Schutt AJ, Rubin J, Hahn R: Treatment of the malignant carcinoid syndrome. Evaluation of a long-acting somatostatin analogue. $\mathrm{N}$ Engl J Med 315:663-666, 1986

36. Richter G, Stockmann F, Lembeke B, Conlon JM, Creutzfeldt W: Short-term administration of somatostatin analogue SMS 20-1995 in patients with carcinoid tumors. Scand J Gastroenterol 21(suppl 119):193-198, 1986

37. Kvols LK, Martin JK, Marsh HM, Moertel CG: Carcinoid crisis: Rapid reversal of the life-threatening hypotension with a somatostatin analogue. N Engl J Med 313:1229, 1985

38. Santangelo WC, O'Dorisio TM, Kim JG, Severino G, Krejs GJ: Pancreatic cholera syndrome-effect of a synthetic somatostatin analogue on intestinal water and ion transport. Ann Intern Med 103:363-367, 1985

39. Vinik A, Tsai S, Moattarri A, Cheung P, Eckhauser F, Cho $\mathrm{K}$ : Somatostatin analogue (SMS 201-995) in the management of gastroenteropancreatic tumors and diarrhea syndromes. Am J Med 81(suppl 6b):23-40, 1986

40. Arnold R, Lankisch: Somatostatin and the gastrointestinal tract. Clin Gastroenterol 9:733-754, 1980

41. Stockmann F, Richter G, Lembcke B, Conlon JM, Creutzfeldt W: Long-term treatment of patients with endocrine gastrointestinal tumors with the somatostatin analogue SMS 201-995. Scand J Gastroenterol 21 (suppl 119):230-237, 1986

42. Hengl G, Prager J, Pointner $H$ : The influence of somatostatin on the absorption of triglycerides in partially gastrectomized subjects. Acta Hepato-Gastroenterol 26:392-395, 1979

43. Wood SM, Kraenzlin ME, Adrian TE, Bloom SR: Treatment of patients with pancreatic endocrine tumors using a new long-acting somatostatin analogue: Symptomatic and peptide responses. Gut 26:438-444, 1985

44. Poole CJM: Myelopathy secondary to metastatic carcinoid tumors. J Neurol Neurosurg Psychiatr 47:1359-1360, 1984 


\section{SOMATOSTATIN ANALOG AND CARCINOID SYNDROME}

45. Berry EM, Maunder C, Wilson M: Carcinoid myopathy and treatment with cyproheptadine (periactin). Gut 15:34-38, 1974

46. Green D, Joynt RJ, Van Allen MW: Neuromyopathy associated with a malignant carcinoid tumor. Arch Intern Med 114:494-496, 1964

47. Wroe SJ, Ardon M, Bouden AR: Myasthenia gravis associated with a hormone producing malignant carcinoid tumor. J Neurol Neurosurg Psychiat 48:719-720, 1985
48. O'Stern WK, Barnard JL Jr, Yates RD: Morphologic changes in skeletal muscle induced by serotonin treatment, a light and electron microscopy study. Exp Mol Pathol 7:145155,1967

49. Kraenzlin ME, Ching KC, Wood SM, Carr DH, Bloom SR: Long-term treatment of a VIPoma with somatostatin analogue resulting in remission of symptoms and possible shrinkage of metastases. Gastorenterology 88:185-7, 1985 